\title{
WPŁYW INSTRUMENTÓW WSPÓLNEJ POLITYKI ROLNEJ NA ROZWÓJ GRUP PRODUCENTÓW ROLNYCH W POLSCE W UJĘCIU REGIONALNYM
}

\section{IMPACT OF THE COMMON AGRICULTURAL POLICY INSTRUMENTS ON THE DEVELOPMENT OF AGRICULTURAL PRODUCER GROUPS IN POLAND IN THE REGIONAL CONTEXT}

\section{Dawid BAtA}

Uniwersytet im. Adama Mickiewicza w Poznaniu Instytut Geografii Społeczno-Ekonomicznej i Gospodarki Przestrzennej ul. Krygowskiego 10, 61-680 Poznań dawid.bala@amu.edu.pl

Zarys treści: Celem artykułu jest porównanie zasad i efektów finansowania działalności grup producenckich z funduszy unijnych w ramach PROW 2004-2006, PROW 2007-2013 oraz założeń PROW 2014-2020. Analizie poddano dotychczasowe wykorzystanie środków z działania Grupy producentów rolnych w latach 2004-2014 w ujęciu regionalnym. W badanym okresie fundusze unijne dystrybuowane w ramach Wspólnej Polityki Rolnej były podstawowym instrumentem wpływającym na rozwój grup producenckich w Polsce. Konsekwencją podejmowanych działań było funkcjonowanie 1351 grup producenckich na koniec 2014 r. Występuje jednak silne zróżnicowanie regionalne w popularności do zrzeszania się rolników. Zasady udzielania pomocy finansowej grupom w poszczególnych okresach budżetowych były do siebie zbliżone i ewoluowały w kierunku efektywniejszego wykorzystania wsparcia z punktu widzenia poszczególnych grup, jak i konkurencyjności całego sektora rolnego. Pomimo regionalnego zróżnicowania wymogów w zakresie minimalnej wielkości produkcji rolnej grupy zainteresowanie zrzeszaniem się wśród rolników z województw o najgorszej strukturze agrarnej jest najsłabsze.

Słowa kluczowe: grupy producentów rolnych, Wspólna Polityka Rolna, fundusze unijne.

\section{Wstęp}

Akcesja Polski do Unii Europejskiej w maju 2004 r. otworzyła przed polskim sektorem rolnym możliwości wynikające z włączenia się do Wspólnej Polityki Rolnej. Jak zauważa G. Wójcik (2011), system ten stwarza warunki do rozwoju nowoczesnego rolnictwa oraz umożliwia kreowanie konkurencyjnej gospodarki żywnościowej. Słaba konkurencyjność polskiego rolnictwa, mająca swe pierwotne źródło w niekorzystnej strukturze agrarnej, związana jest również z niechęcią do integracji poziomej wśród producentów rolnych. 
Według J. Wilkina (2010) właśnie niewielka skłonność rolników do działań zbiorowych, kooperacji i tworzenia instytucji współpracy jest jedną z istotnych barier rozwoju polskiego rolnictwa. Potrzeba zrzeszania się rolników, którzy gospodarują przeciętnie na około 10 ha, jest koniecznością, aby mogli sprostać konkurencji (Kożuch 2005; Prus 2008; Wiatrak 2002). W ramach Wspólnej Polityki Rolnej wyodrębniono specjalne instrumenty finansowe mające zachęcać do integracji.

Celem opracowania jest porównanie zasad i efektów finansowania działalności grup producenckich z funduszy unijnych w ramach Planu Rozwoju Obszarów Wiejskich 2004-2006 oraz Programu Rozwoju Obszarów Wiejskich 2007-2013. Dodatkowo dokonano porównania zasad wspierania grup producenckich w ramach Programu Rozwoju Obszarów Wiejskich 2014-2020. Analizie poddano dotychczasowe wykorzystanie środków z działania Grupy producentów rolnych w latach 2004-2014 w ujęciu regionalnym. Postawiono następujące pytania badawcze: 1) Czy i w jakim stopniu instrumenty WPR wpłynęły na poziom integracji producentów rolnych w Polsce? 2) Jakie były zasady wspierania grup producenckich ze środków unijnych i czy ulegały zmianom w czasie? Ponadto dokonano przeglądu dokumentów służących wdrażaniu WPR w Polsce w latach 2004-2020 w kontekście wspierania integracji producentów rolnych. W głównej mierze posłużono się danymi pochodzącymi z ewaluacji działania Grupy producentów rolnych oraz sprawozdań rocznych i bieżących informacji na temat stanu wdrażanych działań publikowanych przez ARiMR.

\section{Wsparcie grup producenckich ze środków krajowych}

Przyjęcie we wrześniu 2000 r. ustawy o grupach producentów rolnych i ich związkach (Dz.U. 2000 nr 88 poz. 983) było pierwszym formalnym krokiem w kierunku integracji polskich rolników. W konsekwencji prawnego usankcjonowania statusu grup producenckich rolnicy zyskali podstawową zachętę do zrzeszania w postaci zwolnienia z podatków od nieruchomości zajętych na potrzeby grupy, podatków dochodowych oraz dostępu do preferencyjnych kredytów. Wprowadzono możliwość uzyskania wsparcia na założenie grupy oraz jej funkcjonowanie w okresie pierwszych 5 lat, jednak maksymalna wysokość pomocy w ciągu roku mogła wynieść zaledwie nieco ponad 200 tys. zł, przy przychodach na poziomie ponad 4 mln zł. Katalog przywilejów finansowanych ze środków krajowych, które miały zachęcić do integracji, okazał się jednak mało atrakcyjny, gdyż do 1 maja 2004 r. założono jedynie 69 grup (Organizowanie... 2010).

\section{Wsparcie grup producenckich w ramach WPR}

Potrzeba zrzeszania się polskich rolników została wyraźnie zaznaczona w Planie Rozwoju Obszarów Wiejskich na lata 2004-2006 poprzez wyodrębnienie specjalnego działania Grupy producentów rolnych, kontynuowanego w kolejnym okresie finansowania. Pierwotny budżet działania wynosił ponad $25 \mathrm{mln}$ euro, jednak mała popularność integracji producentów rolnych w początkowym okresie wdrażania PROW skłoniła decydentów do relokacji środków. Ostateczny budżet wyniósł nieco ponad 6,3 mln euro, jednak dla części grup ubiegających się o wsparcie w końcowym okresie realizacji działania zabrakło środków. Pomoc została udzielona już z nowego budżetu, którego wysokość była znacząco 
wyższa, gdyż wyniosła ponad 182 mln euro. Rosnące zainteresowanie integracją wśród rolników wymaga dalszego zwiększania środków wspierających działalność grupową, dlatego też w ramach PROW 2014-2020 planowana wysokość środków na ten cel uległa ponad dwukrotnemu zwiększeniu.

Wsparcie w poszczególnych okresach budżetowych miało formę ryczałtowych płatności stanowiących procent od wartości rocznej sprzedaży netto, realizowanych w okresie pierwszych 5 lat od uzyskania statusu grupy producentów rolnych, przy czym w ramach PROW 2004-2006 i 2007-2013 określano maksymalną wartość produkcji, powyżej której procent refundacji był obniżany (tab. 1).

Tabela 1. Zasady udzielania wsparcia grupom producentów rolnych w ramach Wspólnej Polityki Rolnej

\begin{tabular}{|c|c|c|c|}
\hline \multirow{2}{*}{ Wyszczególnienie } & \multicolumn{3}{|c|}{ Okresy finansowe Wspólnej Polityki Rolnej } \\
\hline & PROW 2004-2006 & PROW 2007-2013 & PROW 2014-2020 \\
\hline Nazwa działania & $\begin{array}{l}\text { Grupy producentów } \\
\text { rolnych }\end{array}$ & $\begin{array}{l}\text { Grupy producentów } \\
\text { rolnych }\end{array}$ & $\begin{array}{l}\text { Tworzenie grup i organiza- } \\
\text { cji producentów }\end{array}$ \\
\hline Budżet działania & $6,38 \mathrm{mln}$ euro & $182,5 \mathrm{mln}$ euro & $402,99 \mathrm{mln}$ euro \\
\hline $\begin{array}{l}\text { Zasady naboru } \\
\text { wniosków }\end{array}$ & $\begin{array}{l}\text { Nabór ciągły } \\
(15.12 .2004-31.12 .2007)\end{array}$ & $\begin{array}{l}\text { Nabór ciągły } \\
\text { (16.07.2007-31.12.2013) }\end{array}$ & $\begin{array}{l}\text { Nabór ciągły dla grup } \\
\text { zarejestrowanych } \\
\text { po } 1 \text { stycznia } 2014 \text { r. }\end{array}$ \\
\hline Forma wsparcia & $\begin{array}{l}\text { Ryczałtowe płatności } \\
\text { realizowane w okresie } \\
5 \text { lat od uzyskania statusu } \\
\text { GPR stanowiącej procent } \\
\text { rocznej wartości sprzedaży } \\
\text { netto, tj. } 5 \%, 5 \%, 4 \%, 3 \% \\
\text { i } 2 \% \text { wartości produkcji } \\
\text { do sumy } 1 \text { mln euro w ko- } \\
\text { lejnych latach i odpowied- } \\
\text { nio } 2,5 \%, 2,5 \%, 2 \%, 1,5 \% \\
\text { i 1,5\% nadwyżki ponad } \\
1 \text { mln euro }\end{array}$ & $\begin{array}{l}\text { Ryczałtowe płatności } \\
\text { realizowane w okresie } 5 \text { lat } \\
\text { od uzyskania statusu GPR } \\
\text { stanowiącej procent rocz- } \\
\text { nej wartości sprzedaży net- } \\
\text { to, tj. } 5 \%, 5 \%, 4 \%, 3 \% \text { i } 2 \% \\
\text { wartości produkcji do sumy } \\
1 \text { mln euro w kolejnych } \\
\text { latach i odpowiednio 2,5\%, } \\
2,5 \%, 2 \%, 1,5 \% \text { i } 1,5 \% \text { nad- } \\
\text { wyżki ponad } 1 \text { mln euro. } \\
\text { Od maja } 2010 \text { r. grupy } \\
\text { mogły ubiegać się o tzw. } \\
\text { wsparcie wyprzedzające }\end{array}$ & $\begin{array}{l}\text { Ryczałtowe płatności } \\
\text { realizowane w okresie } \\
5 \text { lat od uzyskania statusu } \\
\text { GPR stanowiącej procent } \\
\text { rocznej wartości sprzedaży } \\
\text { netto, tj. 10\%, } 8 \%, 6 \%, 5 \% \text {, } \\
4 \% \text { wartości produkcji }\end{array}$ \\
\hline $\begin{array}{l}\text { Maksymalna roczna } \\
\text { wysokość pomocy }\end{array}$ & 100 tys. euro & 100 tys. euro & 100 tys. euro \\
\hline $\begin{array}{l}\text { Zakładana liczba } \\
\text { beneficjentów }\end{array}$ & $\begin{array}{l}\text { Nie sprecyzowana. } \\
\text { Przy maksymalnych pozio- } \\
\text { mach wsparcia ok. } 65\end{array}$ & 350 & 1809 \\
\hline Zakres pomocy & $\begin{array}{l}\text { Koszty administracyjne } \\
\text { założenia i funkcjonowania } \\
\text { GPR }\end{array}$ & $\begin{array}{l}\text { Koszty administracyjne } \\
\text { założenia i funkcjonowania } \\
\text { GPR oraz inwestycyjne }\end{array}$ & $\begin{array}{l}\text { Koszty administracyjne } \\
\text { założenia i funkcjonowania } \\
\text { GPR oraz inwestycyjne }\end{array}$ \\
\hline
\end{tabular}

Źródło: opracowanie własne na podstawie PROW 2004-2006, 2007-2013 oraz 2014-2020.

W założeniach perspektywy finansowej na lata 2014-2020 przewiduje się zwiększenie refundacji o 50\%, przy nieograniczonej wysokości rocznej sprzedaży. Jednocześnie zarówno w minionych okresach finansowych, jak i aktualnym maksymalna roczna wysokość wsparcia pozostaje na poziomie 100 tys. euro. Należy jednak zaznaczyć, że w poprzednich okresach budżetowych maksymalna wysokość wsparcia była zróżnicowana w poszczególnych latach funkcjonowania grupy od 100 tys. euro w pierwszym roku do 50 tys. euro w piątym. Istotnym elementem wpływającym na atrakcyjność instrumentu było wprowadzenie w maju 2010 r. możliwości ubiegania się przez grupy o tzw. wsparcie wyprzedza- 
jące. Wcześniej grupa otrzymywała pomoc dopiero po pierwszym roku funkcjonowania, co w pewnym stopniu stanowiło ograniczenie, gdyż rolnicy są niechętni zakładaniu i inwestowaniu w funkcjonowanie grupy producenckiej przez tak długi okres w sytuacji stosunkowo dużego ryzyka powodzenia przedsięwzięcia i przeważnie nie najlepszej sytuacji ekonomicznej gospodarstw.

W ramach PROW 2014-2020 przewiduje się utrzymanie możliwości przeznaczania wsparcia na wydatki inwestycyjne, które mogą stanowić pewien element wpływający na trwałość podejmowanych działań grupowych. Brak takiej możliwości w pierwszych latach wdrażania instrumentu pomocowego WPR był powszechnie krytykowany przez grupy producenckie. Ich determinacja na poziomie Komisji Europejskiej pozwoliła uzyskać zgodę na przeznaczanie należnej pomocy na działania inwestycyjne.

Ciągle nikły poziom integracji producentów rolnych w Polsce wymaga kontynuacji mechanizmów, które będą go wspierały. Jednocześnie kilkuletnie doświadczenia wspierania grup producenckich pozwoliły na ujawnienie pewnych patologii w ramach wdrażanego działania, m.in. niska liczebność rejestrowanych grup, która przeważnie jest na minimalnym poziomie 5 członków. Dodatkowo zauważono wątpliwą skuteczność działania w odniesieniu do grup tworzonych przez osoby prawne, które - jak można przypuszczać - nierzadko powstawały przez sztuczne wydzielanie nowych podmiotów funkcjonujących wcześniej jako całość, których jedynym celem było pozyskanie wsparcia. Wobec czego postanowiono w nowym okresie wyłączyć ze wsparcia grupy tworzone przez osoby prawne oraz branżę drobiarską, którą uznano za stosunkowo silną ekonomicznie. W PROW 2014-2020 zapowiedziano potrzebę preferowania grup liczniejszych, które są efektywniejsze oraz działających w formie spółdzielni, gdyż tego typu organizacja lepiej sprawdza się w warunkach dużej dysproporcji pomiędzy gospodarstwami rolnymi.

Grupy producentów rolnych w ramach PROW 2007-2013 mogły być również beneficjentami działań: Zwiększanie wartości dodanej podstawowej produkcji rolnej i leśnej , Tworzenie i rozwój mikroprzedsiębiorstw oraz Działania informacyjne i promocyjne, jednak rzadko korzystały z tej pomocy. Działanie Grupy producentów rolnych, które jest im wyłącznie dedykowane, stanowi podstawową formę pomocy dla grup producenckich, co potwierdza m.in. E. Kacprzak (2010). W nowym okresie budżetowym akcentowana jest słuszna potrzeba szerszego włączenia grup producenckich do absorpcji środków z innych działań, aby podejmowane przedsięwzięcia były spójne, a co za tym idzie efektywniejsze.

\section{Efekty finansowania grup producenckich w ramach WPR}

W latach 2001-2014 liczba rejestrowanych grup producenckich stopniowo rosła; przeciętnie rolnicy rocznie powoływali ponad 119 grup. Analizowany okres możemy wyraźnie podzielić na dwa etapy. Pierwszy obejmuje lata przed rozpoczęciem wsparcia ze środków unijnych, drugi - to czas wyraźnego ożywienia po wypłacie pierwszym grupom pomocy z PROW 2004-2007. Wyraźny wzrost popularności grup producenckich wystąpił w 2007 r., w którym rolnicy powołali 104 grupy (ryc. 1). Na zaistniałą sytuację wpłynęły zapewne dobre praktyki w tym zakresie, jak również nałożenie się możliwości korzystania z pomocy zarówno z PROW 2004-2006, jak i rozpoczęcie naborów w ramach kolejnego okresu budżetowego. Rolnicy najaktywniej integrowali się w 2013 r., w którym zarejestrowano prawie 36\% ogółu istniejących GPR na koniec 2014 r. 


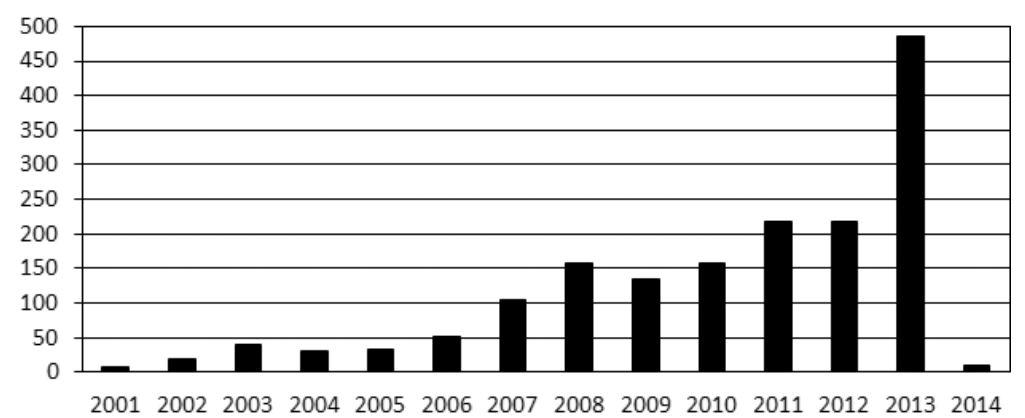

Ryc. 1. Grupy producentów rolnych rejestrowane w latach 2001-2014 w Polsce Źródło: opracowanie własne na podstawie wojewódzkich rejestrów grup producentów rolnych. Agricultural producer groups registered in Poland in years 2001-2014

Source: own study based on voivodship agricultural producer groups' registries.

Zwiększona aktywność rolników w zakresie tworzenia grup producenckich wyraźnie jest powiązana z możliwościami skorzystania z instrumentów WPR, które zostały uruchomione w grudniu 2004 r. O znaczeniu wsparcia z działania Grupy producentów rolnych może świadczyć gwałtowne zahamowanie działań integracyjnych z początkiem roku 2014, kiedy w sytuacji braku jednoznacznych zasad przyznawania pomocy w ramach PROW 2014-2020 rolnicy przeważnie wstrzymali się z decyzją o rejestracji grupy, czego konsekwencją było powołanie zaledwie 10 podmiotów. Należy pokreślić, że założony w ramach PROW 2007-2013 wskaźnik produktu w postaci liczby zarejestrowanych grup na poziomie 350 został wykonany już w trzecim roku wdrażania działania.

Poziom zawansowania integracji producentów rolnych w ramach grup producenckich jest silnie zróżnicowany przestrzennie (ryc. 2). Na koniec 2014 r. najwięcej grup funkcjonowało w województwie wielkopolskim (419). Najsłabiej zorganizowani byli rolnicy z województw świętokrzyskiego (15) i małopolskiego (19). Niewielka liczba grup producentów rolnych w województwach południowo-wschodniej Polski pokazuje, że niższe minimalne limity produkcji rolniczej wymagane przy ich rejestracji, są niewystarczającą zachętą do integracji.

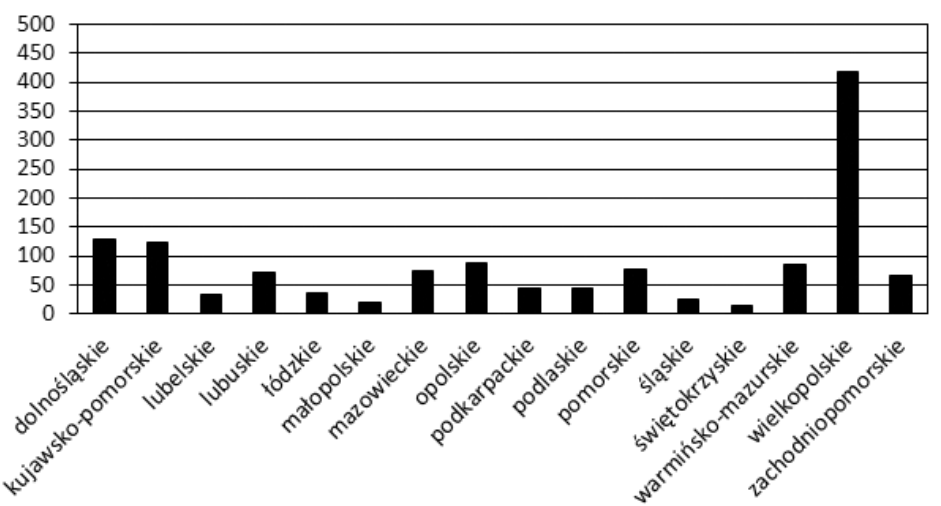

Ryc. 2. Liczba zarejestrowanych grup producenckich w Polsce według województw; stan na 31.12.2014 r. Źródło: opracowanie własne na podstawie danych MRiRW. Number of registered agricultural producer groups in Poland by voivodships; as of 31.12.2014 r Source: own study based on MRiRW data. 
Absorpcja środków unijnych przez grupy producenckie w latach 2004-2014 charakteryzuje się dużym zróżnicowaniem regionalnym. Grupy pozyskały od nieco ponad 700 zł/100 ha użytków rolnych w województwie małopolskim, do ponad 11 tys. zł w województwie opolskim (ryc. 3).

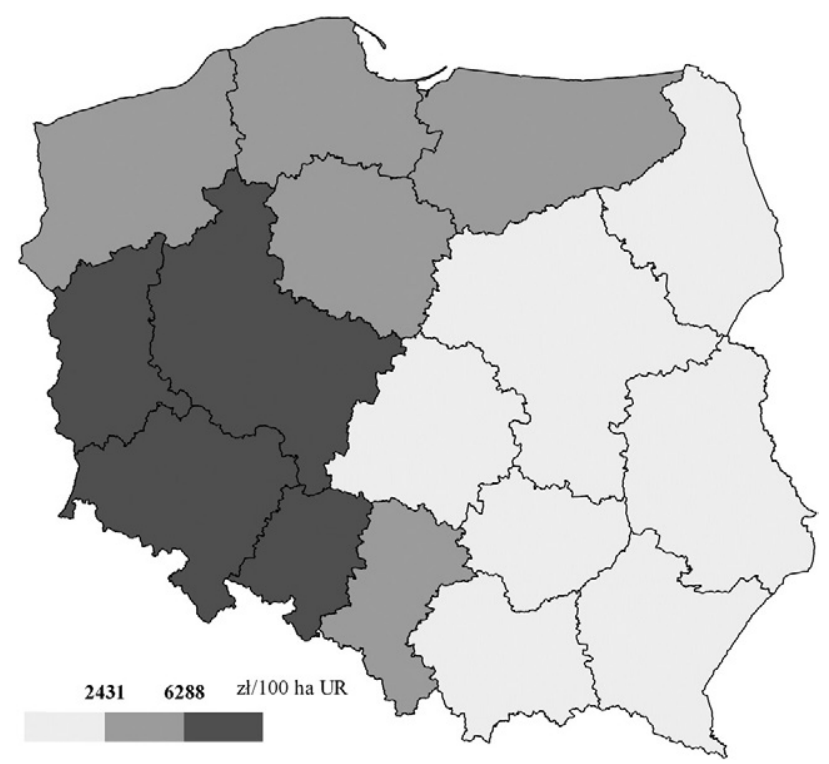

Ryc. 3. Wysokość pomocy finansowej udzielonej grupom producentów rolnych w ramach WPR w latach 2004-2014 Źródło: opracowanie własne na podstawie danych ARiMR.

Amount of financial support provided to agricultural producer groups under the Common Agricultural Policy in years 2004-2014

Source: own study based on ARiMR data.

Najwięcej środków pozyskano w regionach o prężnym rolnictwie, takich jak województwa: opolskie, wielkopolskie, dolnośląskie, gdzie jednocześnie działalność grupowa jest najbardziej popularna. Wyjątkowo duża efektywność grup producenckich z terenu województwa lubuskiego na poziomie ponad 11 tys. zł/100 ha UR, może być związana z wysokim poziomem organizacji producentów drobiu na tym obszarze oraz wyższą przeciętną powierzchnią gospodarstw w stosunku do pozostałych regionów o najwyższym poziomie organizacji producentów rolnych.

Przeciętnie grupy w analizowanym okresie pozyskały prawie 4,3 tys. zł na 100 ha użytków rolnych. Znacznie mniejsze wsparcie trafiło do województw południowo-wschodniej Polski, w których grupy średnio pozyskały ponad sześciokrotnie mniejszą pomoc niż w województwach o najwyższym poziomie absorpcji. Dysproporcje regionalne w wysokości pozyskanych środków potwierdzają tradycyjny już podział kraju wynikający z zaszłości historycznych i związanych z tym różnic tkwiących w mentalności samych rolników.

Bezwzględnym liderem organizacji producentów rolnych jest województwo wielkopolskie, na terenie którego na koniec 2014 r. funkcjonowało ponad 30\% ogółu istniejących grup producenckich. O aktywności wielkopolskich grup w zakresie pozyskiwania środków unijnych świadczy liczba wydanych decyzji przyznających pomoc. W latach 2004-2014 łącznie wydano ich 3384, z czego prawie 25\% dotyczyło grup z Wielkopolski. W gronie 
województw o dużej liczbie wydanych decyzji wyróżnia się województwo kujawsko-pomorskie, na terenie którego grupy były szczególnie aktywne w początkowym okresie i to właśnie tam w ramach PROW 2004-2006 wydano najwięcej decyzji, a grupy pozyskały największe wsparcie w przeliczeniu na 100/ha UR.

Należy zauważyć, że o ile w okresie wdrażanie działania Grupy producentów rolnych w ramach PROW 2004-2006, które miało charakter pilotażowy, nie we wszystkich województwach grupy ubiegały się o pomoc (podlaskie i łódzkie), to w kolejnym okresie taka sytuacja się już nie powtórzyła (ryc. 4). Nie mniej jednak w województwach o najniższym poziomie konkurencyjności rolnictwa jak małopolskie czy podkarpackie, gdzie działalność grupowa wydaje się być najbardziej potrzebna, zmiany w zakresie integracji zachodzą najwolniej, jeżeli porównamy liczbę wydanych decyzji. Największą dynamiką zmian w zakresie liczby wydanych decyzji charakteryzuje się województwo warmińsko-mazurskie, w przypadku którego liczba ta wzrosła z 9 do 224.

Ze względu na to, że przyznawane grupom wsparcie jest pochodną wielkości ich produkcji, analiza wysokości otrzymanej pomocy przypadającej na jedną decyzję pozwala określić potencjał korzystających ze wsparcia grup. Średnia wysokość udzielonej pomocy przypadająca na decyzję (grupę) w latach 2004-2014 wyniosła ponad 185 tys. zł. Wysokość przypadającego wsparcia na decyzję jest zróżnicowana regionalnie, od zaledwie nieco ponad 131 tys. zł w województwie małopolskim do ponad 246 tys. zł w lubuskim.

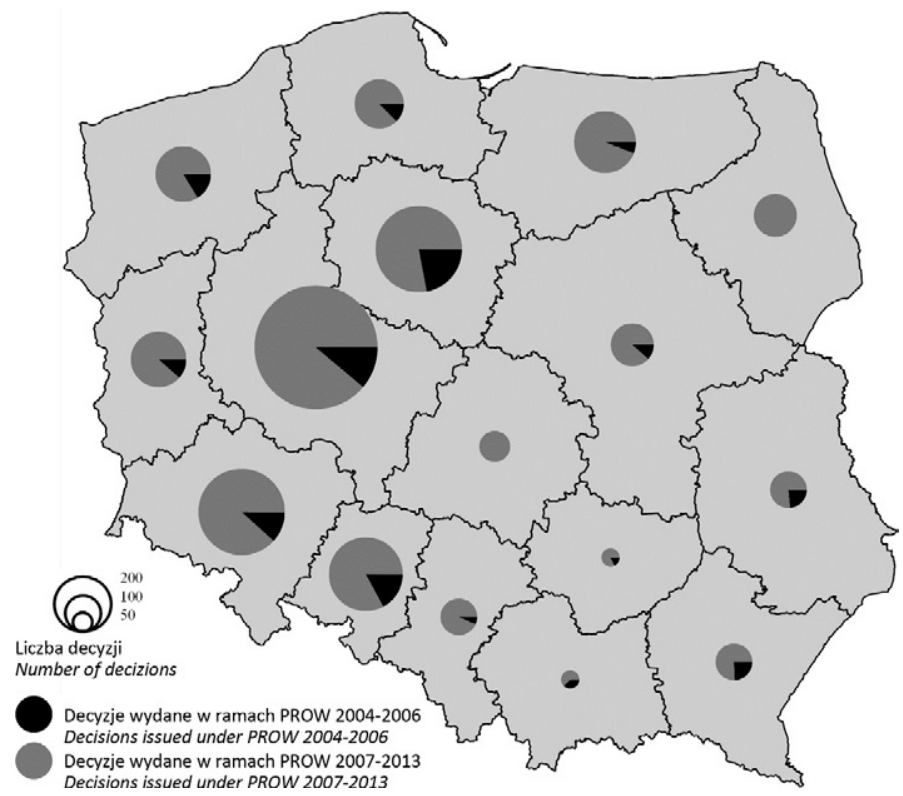

Ryc. 4. Liczba decyzji przyznających wsparcie grupom producentów rolnych w latach 2004-2014 Źródło: opracowanie własne na podstawie danych ARiMR.

Number of decisions granting support to agricultural producer groups in years 2004-2014 Source: own study based on ARiMR data.

Najmniej funduszy pozyskały grupy z województw: małopolskiego, lubelskiego i podkarpackiego. Należy zwrócić uwagę, że w województwach o najwyższym poziomie integracji producentów rolnych, takich jak wielkopolskie czy opolskie, przeciętnie grupy 
pozyskały mniej środków, gdyż rozszerzająca się popularność działań grupowych prowadzi do powstawania coraz większej liczby grup z minimalną liczbą członków i nie największym potencjałem produkcyjnym. Dodatkowo warto podkreślić, że istniejące grupy są w większości zamknięte na przyjmowanie członków, w konsekwencji czego rolnicy, idąc za przykładem innych, powołują nowe podmioty (Oceny efektów... 2014).

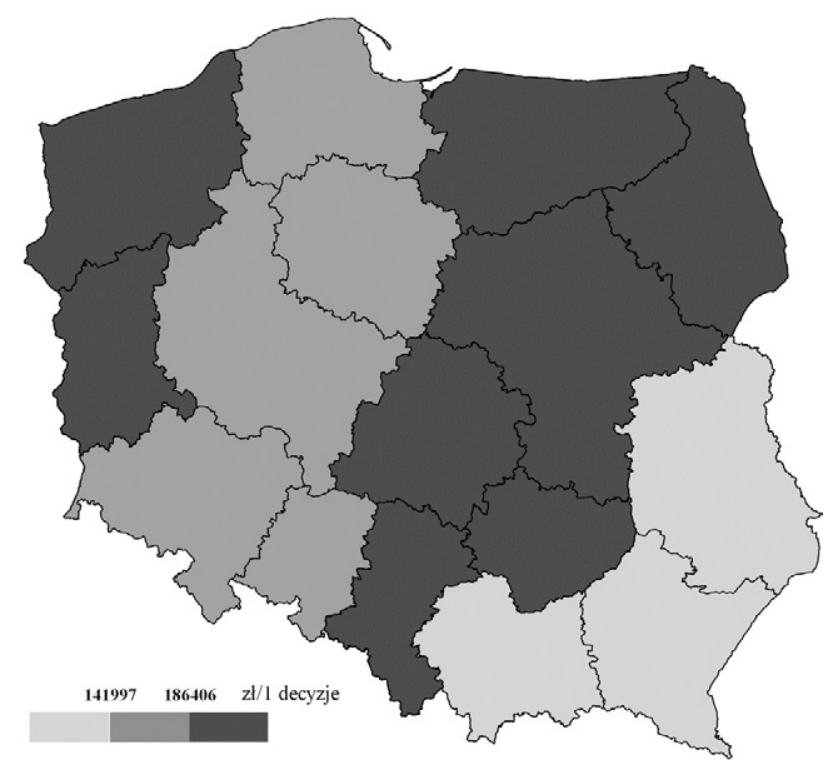

Ryc. 5. Wysokość przyznanej pomocy grupom producentów rolnych przypadająca na 1 decyzję w latach 2004-2014 Źródło: opracowanie własne na podstawie danych ARiMR.

Amount of support granted to agricultural producer groups per 1 decision in years 2004-2014

Source: own study based on ARiMR data.

W grupie województw o najwyższej wysokości wsparcia przypadającej na decyzję dominują te z północno-zachodniej i północno wschodniej Polski charakteryzujące się wysoką przeciętną powierzchną gospodarstw. W gronie województw o wsparciu przekraczającym 186 tys. zł na decyzję znajdziemy również regiony o dużo gorszej strukturze agrarnej, jak świętokrzyskie, śląskie czy łódzkie, w przypadku których prawdopodobnie o wysokiej absorpcji zadecydowały grupy skupiające producentów działów specjalnych rolnictwa.

\section{Podsumowanie}

Instrumenty Wspólnej Polityki Rolnej w znaczący sposób przyczyniły się do popularyzacji idei grup producentów rolnych w Polsce, w konsekwencji czego na koniec 2014 r. funkcjonowało 1351 grup. Wzrost liczby rejestrowanych grup jest widoczny po akcesji Polski do Unii Europejskiej i uruchomieniu wsparcia w ramach działania Grupy producentów rolnych. Wysoka atrakcyjność unijnej pomocy finansowej i dobre praktyki zdobyte w ramach PROW 2004-2006 doprowadziły do zawiązania w 2013 r. 485 grup producenckich, tj. 36\% ogółu istniejących GPR na koniec 2014 r. O dużym wpływie środków pomoco- 
wych na ich rozwój może świadczyć znaczący spadek liczby rejestrowanych podmiotów w 2014 r., w sytuacji braku usankcjonowania prawnego dystrybucji środków pomocowych w ramach PROW 2014-2020.

Zasady udzielania pomocy finansowej grupom w poszczególnych okresach budżetowych były do siebie zbliżone i ewoluowały w kierunku efektywniejszego wykorzystania wsparcia z punktu widzenia poszczególnych grup, jak i konkurencyjności całego sektora rolnego. Szczególnie istotnej zmiany dokonano w okresie wdrażania PROW 2007-2013, gdzie dopuszczono możliwość finansowania zamierzeń inwestycyjnych grup producenckich ze środków przekazywanych na założenie i funkcjonowanie grup. Możliwość udzielania tzw. wsparcia wyprzedzającego, wprowadzona w 2010 r., była niewątpliwie jedną z ważniejszych modyfikacji systemu udzielania wsparcia. Pozwoliło to w pewnym zakresie zniwelować barierę finansową tworzenia grup.

Regionalnie zróżnicowanie poziomu integracji rolników skłania do zwrócenia uwagi na dostosowanie instrumentów pomocowych do specyfiki poszczególnych regionów. Szczególnym wyzwaniem stojącym w ramach perspektywy finansowej na lata 2014-2020 jest upowszechnienie integracji poziomej wśród gospodarstw z południowo-wschodniej Polski, która w warunkach niekorzystnej struktury agrarnej może znacząco przyczynić się do poprawy ich konkurencyjności.

Zakładany wzrost wysokości wsparcia w ramach PROW 2014-2020 oraz dobre praktyki funkcjonujących grup wpłyną na dalszy rozwój grup producenckich. Należy jednak zwrócić uwagę na trwałość powstających podmiotów, gdyż lepsze warunki finansowe mogą skłonić do sztucznego powoływania nowych grup i likwidacji dotychczasowych.

\section{Literatura}

Kacprzak E., 2010, Pozyskiwanie środków finansowych Wspólnej Polityki Rolnej przez grupy producenckie w Polsce, Studia Obszarów Wiejskich, 24, s. 99-119.

Kożuch A., 2005, Współczesne warunki współdziałania na wsi. Agrobiznes 2005. Zmiany w agrobiznesie po przystapieniu Polski do Unii Europejskiej, Prace Naukowe Akademii Ekonomicznej we Wrocławiu, 1070, Wrocław, s. 496-500.

Ocena efektów wsparcia udzielonego w ramach działania 142 "Grupy producentów rolnych" Programu Rozwoju Obszarów Wiejskich na lata 2007-2013 (PROW 2007-2013), 2014, Ministerstwo Rolnictwa i Rozwoju Wsi, Warszawa.

Organizowanie się gospodarcze polskich rolników po 1990 roku, 2010, Krajowa Rada Spółdzielcza, Warszawa.

Plan Rozwoju Obszarów Wiejskich na lata 2004-2006, 2004, Ministerstwo Rolnictwa i Rozwoju Wsi, Warszawa.

Program Rozwoju Obszarów Wiejskich na lata 2007-2013, 2015, Ministerstwo Rolnictwa i Rozwoju Wsi, Warszawa.

Program Rozwoju Obszarów Wiejskich na lata 2014-2020, 2014, Ministerstwo Rolnictwa i Rozwoju Wsi, Warszawa.

Prus P., 2008, Rola grup producenckich w podnoszeniu konkurencyjności gospodarstw rolnych, Roczniki Naukowe Stowarzyszenia Ekonomistów Rolnictwa i Agrobiznesu, 10, 3, s. 456-461.

Ustawa z dnia 15 września 2000 r. o grupach producentów rolnych i ich związkach oraz o zmianie innych ustaw (Dz. U. Nr 88, poz. 983 ze zm.) 
Wiatrak A.P., 2002, Przedsiębiorczość zespołowa w agrobiznesie, Roczniki Naukowe SERiA, 4, 6, s. $181-185$.

Wilkin J., 2010, Skutki transformacji postsocjalistycznej i członkostwa Polski w Unii Europejskiej dla wsi i rolnictwa - próba podsumowania, [w:] J. Wilkin, I. Nurzyńska (red.), Polska wieś 2010. Raport o stanie wsi, Wydawnictwo Naukowe Scholar, Warszawa, s. 170-178.

Wójcik G., 2011, Wspólna Polityka Rolna i jej wpływ na rozwój rolnictwa i obszarów wiejskich po akcesji w Unii Europejskiej, Wiadomości Zootechniczne, 49, 2, s. 61-68.

\section{Summary}

The aim of this paper is to compare policies and effects of financing the activities of producer groups by the EU funds in the financing periods: 2004-2006, 2007-2013 and 2014-2020. The use of funds from the action "agricultural producer groups" hitherto for the period 2004-2014 was examined by region. In the analysed period the EU funds distributed under the Common Agricultural Policy were the basic instrument influencing the development of producer groups in Poland, and consequently at the end of 2014 there functioned 1351 groups. The rules for granting financial support to groups across budget periods were similar and evolved towards more efficient use of support from the point of view of individual groups, as well as the competitiveness of the entire agricultural sector. The projected increase in the amount of support and good practices of the operating groups are likely to affect further development of producer groups. 